\title{
Love as a Source of Illness in Late Eighteenth-Century Sweden - Examples from the Life Description of Pehr Stenberg
}

\author{
Ina Lindblom | ORCID: 0000-0002-9397-3973 \\ Umeå University, Umeå, Sweden \\ ina.lindblom@umu.se
}

\begin{abstract}
Through the analysis of an extensive biographical source material - the life description of Swedish clergyman Pehr Stenberg - this article examines how love was framed as a cause of illness in everyday contexts in late eighteenth-century Sweden. Love was perceived as an emotion that could cause both physical and mental forms of illness. Although lovesickness has been regarded as an illness that could be used by afflicted individuals to communicate emotions, this source material indicates that illnesses caused by love were regarded as actual afflictions. In the framing of these illnesses, conceptions of female fragility were reinforced as love was perceived to have a particularly destabilising power on women.
\end{abstract}

\section{Keywords}

lovesickness - love - medical history - framing illness - gender

In 1786, while a student of theology in Åbo, young Swede Pehr Stenberg together with some friends went into the forest outside town to look at a hut belonging to a female hermit, locally known as the 'the forest maid'. Now between seventy and eighty years old, this woman had lived in the forest for several decades. Stenberg describes hearing much about this strange person, who was said to be the daughter of a lieutenant. The woman was widely believed to be mad:

It was said that she was out of her senses; sometimes she was said to have plucked all the feathers off her hens and let them run around naked. And 
if, during her absence from home, boys had damaged her hut or her other possessions, she said that the subterranean people had done so. ${ }^{1}$

Stenberg ends his account with a brief conclusion that it was probably 'some unhappy love in her youth which had brought her to this peculiar way of life', thereby drawing a direct link between unhappiness in love and lifelong madness. ${ }^{2}$ According to Stenberg's description, the effects of this had been detrimental, permanently and profoundly altering the course of this woman's life.

The aim of this essay is to examine love as a source of both physical and mental illness in everyday contexts in late eighteenth-century Sweden, with a specific focus on gender. Emphasis is placed on instances where an emotion in this case love - was regarded as the main cause of an illness. During the early modern period, the interrelation between emotional experience and illness was often presumed. ${ }^{3}$ This essay seeks to examine the links between emotional experience and individual health and discuss the medical and social consequences of defining love as the main cause of an illness. Similar to today, illness during the early modern period was 'not only a sequence of biological processes but also a complex social event defined by prevailing norms and behaviors'. It could be argued that illnesses perceived to be caused by emotions constituted particularly complex social events. In this essay, I follow historian of medicine Charles E. Rosenberg in using the concept of 'framing' to emphasise the way in which disease (or illness) ${ }^{5}$ functions as a 'structuring factor in social situations'. ${ }^{6}$ According to Rosenberg, disease can at the same

1 Pehr Stenberg, Pehr Stenbergs levernesbeskrivning: av honom själv författad på dess lediga stunder, ed. Fredrik Elgh, Göran Stenberg, and Ola Wennstedt, 5 vols (Umeå: Forskningsarkivet vid Umeå universitet, 2014-2018), 2:163. All quotes from the source material were translated by the author.

2 Stenberg, Levernesbeskrivning, 2:163.

3 See, for instance, Ulinka Rublack, 'Fluxes: The Early Modern Body and the Emotions,' trans. Pamela Selwyn, History Workshop Journal 53 (2002): 1-16; Olivia Weisser, Ill Composed: Sickness, Gender, and Belief in Early Modern England (New Haven: Yale University Press, 2005).

4 Weisser, Ill Composed, 2.

5 Although it is notoriously difficult to make a clear distinction between illness and disease, the term illness with its more subjective experiential connotations will be used going forward rather than 'disease' with its more objective pathological dimension. For a discussion of these concepts see Kenneth M. Boyd, 'Disease, Illness, Sickness, Health, Healing and Wholeness: Exploring Some Elusive Concepts,' Medical Humanities 26, no. 1 (2000): 9-17. It is worth noting that this distinction does not exist in the Swedish language, where 'disease' and 'illness' are encompassed by the word sjukdom.

6 Charles E. Rosenberg, 'Introduction,' in Framing Disease: Studies in Cultural History, ed. Charles E. Rosenberg and Janet Golden (New Brunswick, NJ: Rutgers University Press, 1992), 
time be a biological event, an aspect of social role and individual identity and a sanction for cultural responses. Rosenberg regards the act of diagnosis as the 'key event in the experience of illness.' ${ }^{7}$ In this essay, focus is placed on diagnosis and framing processes that took place in lay rather than professional contexts. Lay perceptions of illness were central in Sweden, as laymen were usually responsible for diagnosing and treating illness. ${ }^{8}$ In analysing the social dimensions of illness related to love, I make use of Monique Scheer's concept of communicating emotional practices. This concept is used in order to highlight the communicative dimensions of illness perceived to be caused by love. ${ }^{9}$ The analysis is based on a peculiar source document - the life description of Pehr Stenberg.

\section{Pehr Stenberg and His Life Description}

Pehr Stenberg (1758-1824) was born to an impoverished farmer just outside the northern coastal town of Umeå, a town with fewer than 1,0oo inhabitants. Like most Swedish children of the time, Stenberg was taught to read by his parents. ${ }^{10}$ He showed intellectual promise from an early age and after being given permission by the parish to beg for his tuition, Stenberg had the opportunity to become a clergyman through studies at Åbo Academy (in presentday Finland). ${ }^{11}$ During his studies, Stenberg first worked as a tutor and later as a house chaplain for aristocratic families in the countryside outside of Åbo. ${ }^{12}$ In 1789 he returned home to work as a curate, before being promoted to assistant vicar. Initially unsuccessful in his courtships of women of higher social standing, he married his housekeeper, Elisabeth 'Lisa' Ålund. In 1796, she died in childbirth along with the set of twins she had been carrying. The same

xviii. For a further development of the concept of framing, see Framing and Imagining Disease in Cultural History, ed. G. S. Rousseau et al. (Basingstoke: Palgrave Macmillan, 2003).

7 Rosenberg, 'Introduction,' xviii.

8 This is described in further detail below.

9 Monique Scheer, 'Are Emotions a Kind of Practice (and Is That what Makes Them Have a History)? A Bourdieuian Approach to Understanding Emotion,' History and Theory 51, no. 2 (2012): 193-220 (214).

10 The level of literacy was relatively high among the Swedish population during the eighteenth century.

11 Finland was part of the Swedish realm from the Middle Ages until 1809, when it was lost to Russia.

12 Members of the nobility could be extended the privilege of employing a private clergyman if they were unable to attend regular service in the state church. 
year Stenberg remarried. His new wife, Elisabeth Catharina Turdfäll, was the daughter of an army major from a noble background. The couple had nine children.13

Stenberg's life experiences are depicted in a close to 5,000-page manuscript that he worked on for over forty years, starting in his twenties and continuing until the year of his death. Stenberg began writing his manuscript just as the genre of autobiography was beginning to take shape. ${ }^{14}$ However, it cannot easily be defined as a work of autobiography. It is a peculiar hybrid document, a mixture between an emotionally revealing account of the self and an ethnographic observation of the practical details of everyday life, such as fishing techniques. ${ }^{15}$ From a Swedish perspective, it is unmatched in scope and detail. It is evident that Stenberg used diaries or extensive notes (now lost) made in temporal proximity to the events depicted, and later rewrote these as a larger narrative, sometimes with a lag of ten to twenty years. His work also includes a large number of excerpts from letters, both sent and received, and sections of written dialogue. It also contains poems and song lyrics composed by Stenberg himself. Stenberg mainly intended the work for his descendants, who are directly addressed throughout the text. ${ }^{16}$ However, he did consider posthumous publication as a possibility and marked sections of the text to be excluded from publication. Nevertheless, no parts of the manuscript were published until the present day; instead, it remained in Stenberg's family until the 196os when it was deposited in the Swedish Royal Library. ${ }^{17}$

One of the inspirations for Stenberg's work came after he attended a seminar in Åbo held by theologian Henrik Gabriel Porthan. Porthan spoke of the fledgling science of psychology and claimed that this would be unable to develop if people did not start to record the innermost workings of their soul to a larger extent. ${ }^{18}$ Stenberg decided to do so, and this ambition comes across clearly in his work. What starts out as a religiously didactical description of childhood events quickly becomes more personal and confessional, with Stenberg at times exhibiting an almost compulsive drive to share intimate

13 Fredrik Elgh and Göran Stenberg, 'Den långa bildningsresan,' Västerbotten 4 (2011): 3-9.

14 Robert Folkenflik, 'Introduction: The Institution of Autobiography,' in The Culture of Autobiography: Constructions of Self-Representation, ed. Robert Folkenflik (Stanford: Stanford University Press, 1993), 1-20 (7).

15 Stenberg's work has been analysed from an ethnographic perspective by Alf Arvidsson, 'Everyday Storytelling in the Eighteenth Century: Some Examples from Pehr Stenberg's Life Description,' Fabula 6o, nos. 3-4 (2019), 336-53.

16 Stenberg, Levernesbeskrivning, 3:35.

17 Stenberg, Levernesbeskrivning, 1:9-14.

18 Stenberg, Levernesbeskrivning, 1:388. 
details of his life. This includes descriptions of the paralysing social insecurity he initially experienced in bourgeois and aristocratic environments, as well as painstakingly detailed accounts of the obsessive romantic jealousy he exhibited towards his second wife. ${ }^{19}$

There are two reasons why this source material gives a particularly vivid account of the interrelation between love and illness in an everyday context. The first is because love and courtship were major preoccupations for Stenberg in his youth and, therefore, are themes that leave large imprints on his description. The second is because Pehr Stenberg as a clergyman had an important function in local medical care.

Stenberg's attempts at courtship took place in a society with changing sexual norms. Together with the other Nordic countries, Sweden in the early seventeenth century instituted some of Europe's harshest legal restrictions on premarital and extramarital sexual relations. From this point up until the late eighteenth century, premarital sexual relationships were punished with heavy fines and public shaming practices. This legal framework has been related to the so-called 'Lutheran orthodoxy' of the Swedish state. ${ }^{20}$ In an attempt to decrease the risk of infanticide, absolutist King Gustav III lifted some of the harsher restrictions in 1778 . In effect, this had the consequence of implicitly legitimising premarital sexual relations, and the number of children born out of wedlock increased significantly. The clergy protested against these legal reforms and tried to have them reversed. ${ }^{21}$

Before beginning his studies, Stenberg was thoroughly warned by his father that premarital sexual encounters might jeopardise his prospects of becoming a clergyman. ${ }^{22}$ Simultaneously, as a representative of the Lutheran state church, Stenberg was expected to demonstrate high moral standards, making him constantly mindful of how his behaviour towards women was interpreted by others. Owing to this, Stenberg directed his romantic attention towards becoming engaged - in his view the only legitimate way of gaining intimate contact with a young woman. Up until his first marriage with his housekeeper, Stenberg asked several women belonging to the aristocracy and bourgeoisie to marry him, but his proposals were always rejected. While seemingly a socially insecure clergyman from a peasant background was not an interesting

19 Stenberg's social insecurity figures prominently in Volume 1 of his published description; descriptions of his jealousy take up large parts of Volume 4.

$20 \quad$ Eva Österberg, Folk förr: historiska essäer (Stockholm: Atlantis, 1995), 150.

21 Marie Lindstedt Cronberg, Synd och skam: ogifta mödrar på svensk landsbygd 1680-1880

(Lund: Lunds universitet, 1997), 18 o.

22 Stenberg, Levernesbeskrivning, 1:191. 
prospect for women of higher social standing, Stenberg did attract attention from women of the peasant class, as will be illustrated below.

Stenberg's position as clergyman also meant that he had a special function in the rudimentary forms of medical care carried out at the local level in Swedish society. In eighteenth-century Europe, the medical profession was not a self-evident authority regarding matters of illness and health, but instead competed in a market that included barber-surgeons, midwives and laypeople known to have healing knowledge. ${ }^{23}$ The weak position of the medical profession was particularly notable in the impoverished and sparsely populated nation of Sweden, where governmentally appointed provincial doctors ministered to vast geographical areas by themselves. From the middle of the eighteenth century there were increased efforts to educate clergymen in medical matters, for example through medical treatises aimed directly at the rural clergy. ${ }^{24}$ Thus, the need for some medical knowledge in the vocation of clergyman was clear to Stenberg. While a student in Åbo, he asked a barbersurgeon to teach him how to let blood, and attended lectures in anatomy and neurology. ${ }^{25}$ In his later position as a clergyman, Stenberg was consulted on medical issues, often performed bloodletting and also intervened in local medical practices, for example by trying to persuade a barber-surgeon not to treat internal diseases and not to use superstition in her healing practices. ${ }^{26}$ As a clergyman, he was also supposed to tend to the souls of his parish members and would frequently interact with the mentally ill. ${ }^{27}$ Although Stenberg was medically trained to some extent, it is worth noting that lay perceptions and professional perceptions of illness and the body were often intertwined during this period, in which patients and physicians 'spoke a common language and moved within the same humoral explanatory framework.'28

Stenberg's romantic endeavours and his role in local medical care are both featured in his description of his life. Due to its peculiar mix of genres, Stenberg's work might best be more broadly defined as an ego document or a personal narrative, and as such, it is inherently subjective. Mary Fulbrook and Ulinka Rublack write:

23 Michael Stolberg, Experiencing Illness and the Sick Body in Early Modern Europe (Basingstoke: Palgrave Macmillan, 2011), 61-62.

24 Sten Lindroth, Svensk lärdomshistoria: Frihetstiden (Stockholm: Norstedt, 1989), 420, 444.

25 Stenberg, Levernesbeskrivning, 2:275, 335 .

26 Stenberg, Levernesbeskrivning, 3:19, 54, 59 .

27 Själavård (care of the soul) was an important part of priestly duties: Bengt Erik Eriksson, Vägen till centralhospitalet: två studier om den anstaltsbundna sinnessjukvårdens förhistoria i Sverige (Göteborg: Daidalos, 1989), Chapter 2.

28 Stolberg, Experiencing Illness, 79. See also Weisser, Ill Composed, 2. 
The purpose of reading personal narratives ... is not to recover a more authentic non-discursive voice of subjects, but to use personal narratives to see as far as possible how people worked their way through dimensions of norms and relationships, through conflicting demands, ambivalent fears and other emotions, how men and women gave these meaning, what narrative forms this took and what this meant in a particular context. ${ }^{29}$

Stenberg's life description does not give an objective view of everyday life in eighteenth-century Sweden. However, it does give insight into how illnesses were interpreted, how they functioned in social situations and how conceptions of illness were related to contemporary norms - filtered through the voice of Stenberg. Stenberg's position in this source material also shifts. At times, he is at the centre of events; at other times he carefully registers events from a distance. Although all situations are presented from Stenberg's point of view, this viewpoint was an important one, as Stenberg was a local authority figure who was sought for medical care. Altogether, Stenberg's work offers details on lay perceptions of emotion and illness from a wide range of social environments, something that is rarely found in historical sources.

\section{$2 \quad$ Early Modern Views on Lovesickness}

In Europe, love was medically established as a cause of illness during Greek and Latin antiquity. This medical tradition of lovesickness seems to have largely disappeared from European culture after the fall of the Roman Empire, before being reintroduced in the Middle Ages by way of imported Arabic texts. These medical treatises, among which the Viaticum by Constantine the African became especially influential, were commented and elaborated on extensively over time. ${ }^{30}$

During the Renaissance and early modern period, lovesickness became a firmly established concept in Europe, connoting a form of obsessive unfulfilled erotic desire directed at a specific person. Thus, lovesickness was distinguished from other conditions characterised by a generally heightened sexual

29 Mary Fulbrook and Ulinka Rublack, 'In Relation: The "Social Self" and Ego-Documents,' German History 28, no. 3 (2010): 263-72 (271).

$30 \quad$ Mary Frances Wack, Lovesickness in the Middle Ages: The Viaticum and its Commentaries (Philadelphia: University of Pennsylvania Press, 1990), 149; Jacalyn Duffin, Lovers and Livers: Disease Concepts in History (Toronto: University of Toronto Press, 2005), Chapter 2. 
drive, leading Swedish botanist and physician Carl von Linnaeus to describe lovesickness as a 'foolish yet virtuous desire to come close to one's beloved' ${ }^{31}$ Largely defined as a form of melancholy, this diagnosis could also be termed erotic melancholy or erotomania. ${ }^{32}$ Typical symptoms of lovesickness included insomnia, loss of appetite, exhaustion, depression, speechlessness and withdrawal from social life. If left untreated, lovesickness was believed to result in mania - a state during which individuals could tear their clothes, babble in a sexually explicit manner and become violent or suicidal. ${ }^{33}$

The main medical theory underpinning the conception of lovesickness was humoral pathology, the theory of bodily fluids initially established by Galen of Pergamum during the second century CE. According to this framework, the balance and circulation of the four humours - blood, black bile, yellow bile and phlegm - were decisive for both individual health and temperament. ${ }^{34}$ One causal explanation for lovesickness rooted within the theory of humoral pathology was that passion scorched the humours, thereby producing melancholy. Another causal explanation was that excess sperm (viewed as refined blood produced by both men and women alike) generated sexual desire, which could further result in lovesickness if left unfulfilled. However, lovesickness could also be viewed as a form of mental illness where an idealised image of the lover became fixated in the mind, ultimately turning into a phantasm. In accordance with the theory of humoral pathology, bloodletting formed the principal cure for lovesickness, performed in order to promote the balance and circulation of humours. Other solutions could be sexual intercourse to release excess seed, or marriage - simply letting the afflicted start a relationship with the beloved. Another cure amounted to consciously creating an aversion to the desired individual. ${ }^{35}$

Lovesickness was not solely a diagnosis prevalent in medical works, as descriptions of deep suffering from love can be found in doctors' case records

31 Nils Uddenberg and Pehr Osbeck, Linné och mentalsjukdomarna: En kommenterad utgåva av Pehr Osbecks anteckningar om psykiatri under Linnés föreläsningar över temat Systema morborum läsåret 1746-1747 (Stockholm: Atlantis, 2012), 98.

32 The latter term was established by Jacques Ferrand during the early seventeenth century: Jacques Ferrand, A Treatise on Lovesickness, ed. and trans. Donald A. Beecher and Massimo Ciavolella (Syracuse, NY: Syracuse University Press, 199o).

33 Lesel Dawson, Lovesickness and Gender in Early Modern English Literature (Oxford: Oxford University Press, 2008), 17.

34 R. J. Hankinson, ed., The Cambridge Companion to Galen (Cambridge: Cambridge University Press, 2007).

35 Donald A. Beecher and Massimo Ciavolella, 'Introduction,' in Ferrand, Treatise on Lovesickness, 4-5; Dawson, Lovesickness and Gender, 19-26. 
as well as personal letters and diaries from this time. ${ }^{36}$ This suffering included the lower orders of society, as shown in Michael MacDonald's examination of the case notes of the astrologer, clergyman and physician Richard Napier. ${ }^{37}$ However, from a discursive point of view, the diagnosis of lovesickness was defined according to social status and gender. Lesel Dawson points to a long tradition wherein lovesickness was associated with male heroism, with men of the nobility being portrayed as the primary sufferers. While the lovesickness that afflicted men was associated with melancholy, creativity and a philosophical disposition - and thus connected to status - female lovesickness, in contrast, was seen as bodily, passionate and associated with lack of reason. Although Dawson demonstrates that women were not entirely excluded from the more noble expressions of lovesickness, this gendered divide was prominent.

Consequently, lovesickness could form part of a kind of self-fashioning for men but did not function in the same sense for women. ${ }^{38}$ This gendered dimension of lovesickness shifted with time. Clark Lawlor writes that men 'in the cult of courtly love and the later one of melancholy, were the most obvious sufferers of lovesickness, although their role declined along with those social and literary modes. ${ }^{39}$ Sally Holloway argues that lovesickness was feminised during the eighteenth century, up until the point where suffering from love became 'a uniquely female domain'. ${ }^{40}$ According to Holloway, lovesickness to an increasing degree was connected with assumptions of heightened female sensibility and the fragile female constitution. In contrast, male suffering from love became associated with idleness and lack of self-control..$^{41}$ The rise of the concept of sensibility was in itself linked to the growing prominence of nerve theory as a way of explaining both mental and physical states of health. The female nervous organisation was considered weaker than its male counterpart and therefore more excitable and susceptible to nervous pathological conditions, making women more ill-suited to handling powerful emotions. ${ }^{42}$ These

36 Dawson, Lovesickness and Gender, 13-14; Sally Holloway, The Game of Love in Georgian England: Courtship, Emotions and Material Culture (Oxford: Oxford University Press, 2019), 31.

37 Michael MacDonald, Mystical Bedlam: Madness, Anxiety, and Healing in SeventeenthCentury England (Cambridge: Cambridge University Press, 1981), 88-98.

38 Dawson, Lovesickness and Gender.

39 Lawlor, Consumption and Literature: The Making of the Romantic Disease (Basingstoke: Palgrave Macmillan, 2006), 21.

40 Holloway, The Game of Love in Georgian England, 128.

41 Holloway, The Game of Love in Georgian England, 128-33.

42 For more on the gendered view of the nervous system see G.J. Barker-Benfield. The Culture of Sensibility: Sex and Society in Eighteenth-Century Britain (Chicago: University of Chicago Press, 1992); Anne C. Vila, Enlightenment and Pathology: Sensibility in the Literature and 
gendered dimensions of illness caused by love are clearly demonstrated in the life description of Pehr Stenberg. Below, illness caused by love involving physical symptoms will be examined, followed by love's relation to insanity.

\section{Love and Physical Illness in the Life Description of Pehr Stenberg}

Within Stenberg's life description, no specific term such as lovesickness is used to describe ailments caused by love. The symptoms are generally not clearly defined, the afflicted individuals instead being described as just sick (sjuk) or feeling unwell (må illa). Consequently, these ailments do not appear to be connected with a defined diagnostic picture. While this type of affliction is not explicitly gendered by Stenberg or anyone else in this material, most examples of those individuals framed as experiencing illness due to love are relatively young and unmarried women. There is no distinction made according to social status, as women from the peasantry, bourgeoisie and aristocracy are alike assumed to be ill from love. ${ }^{43}$ Consequently, these types of illnesses appear to be gendered, but not related to social background, as they are perceived to afflict women from both lower and higher social orders. This would indicate that these ailments were not a signifier of status, in contrast to many fashionable illnesses during the eighteenth century, which were reserved for individuals of higher social standing. These included conditions such as vapours and hypochondria. ${ }^{44}$

Similar features occur in two examples of women from the peasantry framed in Stenberg's writings as ill from love. In both cases, Stenberg finds himself the object of affection and becomes involved in the treatment of the women. The first incident takes place when he is temporarily working as a curate in an inland village in his home county of Västerbotten in 179o. While taking over work from the mentally unstable local chaplain, Stenberg lodges in the home of a wealthy farmer, alongside a maid called Lisa. Finding her to be the best at

Medicine of Eighteenth-Century France (Baltimore: Johns Hopkins University Press, 1998); Lawlor, Consumption and Literature, $5^{6-57 .}$

43 See examples below for footnotes on peasant and bourgeois women. For an example of an aristocratic woman see Stenberg, Levernesbeskrivning, 2:159.

44 There is extensive research on the fashionable diseases of the eighteenth century. See works referenced in note 42 above. See also John Mullan, Sentiment and Sociability: The Language of Feeling in the Eighteenth Century (Oxford: Clarendon Press, 1988); Clark Lawlor, 'Fashionable Melancholy,' in Melancholy Experience in Literature of the Long Eighteenth Century: Before Depression, 1660-1800, ed. Allan Ingram et al. (Basingstoke: Palgrave Macmillan, 2011), 25-53; Michael Stolberg, Experiencing Illness. 
making his bed, Stenberg specifically asks for her to keep his room. As Stenberg has a keen interest in fishing, the maid is also ordered by his hosts to help him row on his fishing trips. Sometimes they are away until late at night, making Stenberg fearful of public slander. ${ }^{45}$

As Stenberg is starting to reach the end of his stay, the local sexton tells him that there is a rumour circulating around the village that Lisa is his fiancée and that she is in love with him. Stenberg answers by saying that he has given her no reason to believe he is enamoured of her, had no intention of taking her as his wife and had not noticed any feelings on her part. However, he starts to watch her more closely and eventually comes to believe that she is completely infatuated with him. ${ }^{46}$ Stenberg then relates how the maid becomes ill as he is about to leave his position and return to Umeå. The mistress of the household asks Stenberg to let the maid's blood, but this does not improve her state. Instead she becomes bedridden during the last days of his stay. In order to establish his hosts' thoughts on the matter, Stenberg asks the mistress about the nature of the maid's illness and recounts their conversation:

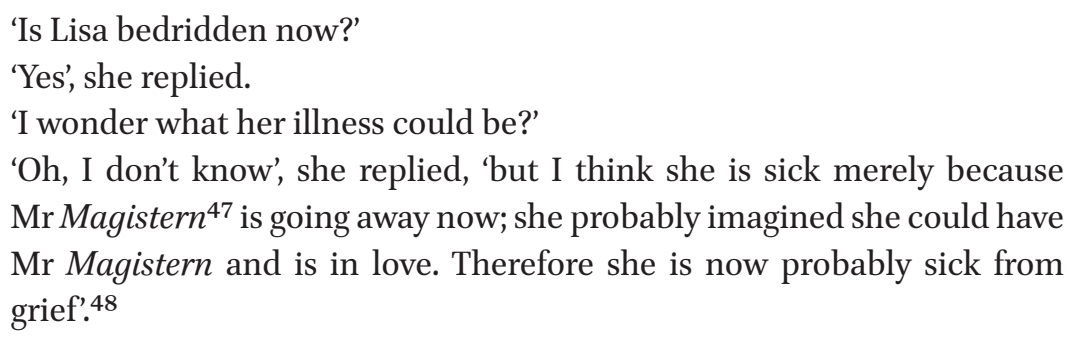

In line with Stenberg's fear of being accused of immoral behaviour towards women, he emphatically reassures his hosts that he had given the maid no reason to believe he had affections for her. He writes that by doing so, he was hoping that his reassurances would reach the other inhabitants of the village and that they would be convinced of the false nature of the rumour being spread about him and the maid. Stenberg adds that he was also hoping that Lisa - over whose predicament he felt compassion and concern - would be informed by the hostess that she had nothing to hope for. He writes that he had sometimes engaged in banter with the girl and asked her questions about her background,

\footnotetext{
45 Stenberg, Levernesbeskrivning, 3:55-58.

46 Stenberg, Levernesbeskrivning, 3:59.

47 During this time, Swedish men were usually addressed using professional or academic titles. Magister was the equivalent of 'master of arts', which was Stenberg's official title after having defended a thesis on buckthorn.

48 Stenberg, Levernesbeskrivning, 3:59.
} 
which he now believes had led her to think he held affections for her. To help her situation, Stenberg attempts to remove her last hope of starting a romantic relationship with him, acting accordingly:

Right when I was ready to depart and had said goodbye to everyone in the village, I went to the maid Lisa, for I did not want to go to her before, so as to not strengthen her in her illusion; but I thought it was too harsh not to say goodbye. She lay in a small chamber, her face turned to the wall. I wanted to give her some tip money, but she would not take it. I then said in a feigned disgruntled and harsh tone: 'Well do so if you like, I will not press you to take it. Farewell to you and be well!', and this very briefly, and only to furtively extinguish her last hope. ${ }^{49}$

We do not know the actual nature of Lisa's illness or how she herself perceived her state. But to the people around her, love was attributed as the cause - more specifically grief over crushed romantic hope. Viewed from the perspective of Rosenberg's framing, love was located as the key component of her diagnosis and so informed how people should respond. This has a crucial bearing on how Stenberg behaves to counteract her illness. As he believes her feelings to be based on an illusion, the best course of action is to crush that illusion entirely - even feigning a harshness he does not feel. Thus, for Stenberg, the cure for Lisa's ailment is mainly emotional. However, it is also clear that Stenberg's wish to not be implicated in her illness influences his actions, as he distinctly manifests his lack of romantic intentions. Additionally, there is a physical dimension to the treatment of her illness, as Stenberg's hosts see bloodletting as a viable option for their distressed maid.

Lesel Dawson has elaborated on the potential functions of lovesickness during the early modern period, arguing that lovesickness could be an indirect way of communicating love or desire to one's object of affection. This could particularly be the case if a romantic relationship was obstructed by outside forces, such as class distinctions, or the fact that the parties were already married. This communicative dimension could also take on manipulative forms as a way of exerting psychological pressure on the beloved. Dawson points to the gendered dimension of this behaviour, writing that 'this is generally a male activity, in which the suitor takes control of his malady, exaggerating or feigning his symptoms in order to woo his mistress by eliciting sympathy from her'. ${ }^{\prime}$ Cases of admitted feigned lovesickness can be found in sources. Mary Frances

49 Stenberg, Levernesbeskrivning, 3:6o.

50 Dawson, Lovesickness and Gender, 42. 
Wack notes how English nobleman Henry of Lancaster (d.1361) admitted to having pretended to be lovesick in order to persuade go-betweens to act on his behalf in his attempted seduction of a woman. ${ }^{51}$ Clark Lawlor notes how future lawyer Dudley Ryder, during the early stages of the eighteenth century, fantasised about becoming ill from lovesickness, thus moving the woman he was infatuated with to feel pity and cure him with her affection. Lawlor notes that Dudley's fantasised illness 'figures as both a position of masculine weakness regarding the object of desire, but also as a possible tool to overcome that weakness by gaining sympathy and, once in possession of the woman, become the dominant player'.52 Although these manipulative dimensions of lovesickness are associated with men, the communicative dimensions inherent in this illness might also have served important functions for women during the early modern period. Olivia Weisser emphasises how the sick body provided a rich site for self-expression, a rare venue in which women could vent their grievances and express their desires within an otherwise limiting patriarchal society'.53 Consequently, exhibiting symptoms of lovesickness could be regarded as a communicative effort. As such it could be termed a communicative emotional practice.

'Communicative emotional practices' are one of the main types of practices defined by Monique Scheer, where emotions 'are perhaps most obviously practices when they are involved in communication. ${ }^{54}$ According to Scheer, it is evident that emotions 'do things' in social contexts and are used as a means of exchange. Scheer writes that reading

emotion in faces, gestures, vocal patterns, bodily postures, or manifestations such as tears, changing skin color, or heavy breathing is a complex process that functions on a multisensory level and involves different modes of knowledge. It includes judgments about the situational context, the actors involved, and social expectations. ${ }^{55}$

Early modern cases of lovesickness imply that illnesses could also be used as a way of communicating emotions, particularly in instances where a more direct form of communication was hindered. Consequently, lovesickness is not a direct mode of emotional communication in the sense described by Scheer,

\footnotetext{
$51 \quad$ Wack, Lovesickness in the Middle Ages, 147.

52 Lawlor, Consumption and Literature, 26.

53 Weisser, Ill Composed, 9.

54 Scheer, 'Are Emotions a Kind of Practice', 214.

55 Scheer, 'Are Emotions a Kind of Practice', 214.
} 
but a state of illness that bears emotional meaning. Thus, illness functions as a way of communicating emotion when the symptoms are interpreted in the manner intended. However, Stenberg does not reflect on a potential communicative intent behind Lisa's illness, as there is no mention of her feigning this ailment in order to communicate with or elicit a response from him. Instead, her illness is interpreted as somatic. According to Stenberg's description, this interpretation was made by her employers as well, who ask that the maid's blood be let and seem to accept her bedridden state rather than define her illness as staged.

This somatic perception of illness related to love is also distinct in a second example where a peasant woman - the housekeeper who would eventually become Stenberg's wife - is framed as falling ill from love. This situation takes place in 1794 after Stenberg has received a permanent position as curate and is living in the town of Umeå. There he has set up his own household with only a housekeeper working for him, a local woman in her early thirties. Stenberg's permanent position finally makes marriage financially viable and he actively searches for a wife whose social standing would confirm his elevation above the peasantry and who would be accepted by his parishioners. However, his low income, non-illustrious background and serious demeanour appear to make finding a wife difficult. While he is courting a clergyman's daughter living in a neighbouring parish, Stenberg becomes both emotionally and physically intimate with his housekeeper. Although Stenberg both kisses and caresses his employee, he makes a point of defining their relationship as 'pure friendship'. ${ }^{6}$ This turn of events is followed by an account of a vague form of illness. During the haymaking season, the housekeeper is primarily responsible for bringing in the hay. While undertaking this, she starts complaining that she is unwell, feeling weak and anxious. Stenberg worries at her inopportune illness and fears that she is overworked. He describes clearly being able to see that she is suffering from 'hanging sickness' (hängsjuka), a state characterised by feeling generally unwell and having low energy. The maid replies that her illness will probably pass if he can let her blood, specifically asking that it be let from her hand rather than her arm, as this had previously helped when she had been anxious. Stenberg writes that he let her blood, but that this did not improve her condition. ${ }^{57}$

As Stenberg comes closer to getting a definitive response from the woman he is courting, he decides that his intimate relationship with his housekeeper must stop and gives her a gift of money in order to convey his regard for her

$5^{6} \quad$ Stenberg, Levernesbeskrivning, 3:347-48.

57 Stenberg, Levernesbeskrivning, 3:348-50. 
virtue and good sense. He describes how, after receiving the gift, the maid broke down in tears and confessed that she had been in love with him for most of her employment in his household, having fought against her feelings but not been able to suppress them. Stenberg, shocked at this revelation, writes that he now surely realised

that the cause of her ... illness and uneasiness, was none other than her love for me, and it especially stemmed from the struggle and battle against it that she had to endure to subdue it and conceal it from me, and which now, from our friendly daily interaction, had naturally become more animated. ${ }^{58}$

According to Stenberg, the maid now also confessed this to be the case, and she admitted to feeling particularly unwell after Stenberg had travelled to get a final answer from the woman he was courting. If one assumes that there were communicative aspects to lovesickness, this episode could certainly be viewed as a communicative effort on the part of the housekeeper - tacitly conveying her love through ill health. However, similar to the example above, Stenberg does not reflect on this illness as a staged effort. Instead, he frames his housekeeper's ailment as both a mental and physical indisposition arising from the prospect of losing the man she loves to another woman. In particular, he mentions her concealment of and attempt to suppress emotions as the cause of ill health. ${ }^{59}$ Consequently, Stenberg's interpretation is based on a presupposed strong somatic connection between emotion and illness, and does not take into consideration the potential social functions of this type of ailment.

Although the examples presented above involve women becoming ill from love, their illnesses are not explicitly gendered by Stenberg. However, the gendered dimensions of illness associated with love are more distinctly demonstrated in a situation that plays out in 1791 when Stenberg has returned to Umeå from Finland and is working as a curate. He is currently unable to support a wife financially but wants to become engaged before all the marriageable women of suitable age and standing have become attached. He forms intentions of asking a distant cousin - Cajsa Magdalena Burgerus - for her hand. However, instead of becoming engaged, Stenberg finds himself the observer of a complicated romantic situation. While temporarily working as a curate in a neighbouring parish, he hears news that Miss Burgerus is very ill. This illness recurs at a later stage, at which Stenberg twice calls on his cousin and finds her

$5^{8} \quad$ Stenberg, Levernesbeskrivning, 3:36o.

59 Stenberg, Levernesbeskrivning, 3:36o-61. 
bedridden. Miss Burgerus's condition becomes a topic of conversation when he visits the home of one of the town's assistant vicars, Nordlund, a few days later. Stenberg recounts how Nordlund's wife

started to speak of Miss Burgerus's illness, about which she uttered something like:- 'Her illness must surely have some specific cause, which must be either deep grief, or some sort of coercion in matters of marriage; this is something we can be sure of.' 60

Stenberg writes that he believed this to be a rash opinion of the girl, thinking that people could easily become sick without such causes. Furthermore, he was unable to see any kind of grief or coercion to marry to which she could be subjected, as he had not heard of her having any suitors. After asking for her hand by letter and not receiving a definitive reply, he later learns that Burgerus already had two suitors - a merchant clerk whom her family were urging her to marry in order to assist in the failing family business, and the local postmaster, Mr Schjåltz, whom she herself wanted to marry and had been seeing in secret for two years. Stenberg writes that he then realised that Mrs Nordlund's remarks regarding the cause of Burgerus's illness had been correct. ${ }^{61}$

Thus, Miss Burgerus's illness was framed as a form of lovesickness, meaning that to parts of the community around her, love troubles - more specifically parental objection to the partner of her choice - were regarded as the cause. According to Lesel Dawson, the psychological uneasiness described in actual cases of lovesickness is indicative of the anxieties associated with the courtship process. As marriage had profound social and economic consequences for both parties, its importance extended far beyond the couple concerned, involving both the family and, at times, the wider community. In this context, the discourse of lovesickness could provide 'an important means of expressing what was sometimes an intractable conflict between physical desire and familial duty'. ${ }^{62}$ Consequently, lovesickness can be viewed as a form of complaint against the pressures exerted by parents or guardians - a complaint which was at times effective as doctors would sometimes recommend that sufferers of lovesickness be allowed to marry the object of their affection. ${ }^{63}$ From the perspective of emotional practices, it could be viewed as a way of indirectly expressing a form of emotional resistance to pressure to act against one's

6o Stenberg, Levernesbeskrivning, 3:171.

61 Stenberg, Levernesbeskrivning, 3:187.

62 Dawson, Lovesickness and Gender, 28.

63 Dawson, Lovesickness and Gender, 31-33. 
feelings and personal inclinations. If Miss Burgerus's illness did in fact constitute a form of resistance to the pressure exerted by her parents, it was unsuccessful, as she finally ended up marrying the merchant clerk, Boström, after much conflict with her parents.

While Stenberg regards illness as a natural outcome of the coercion to which Miss Burgerus was subjected, the emotional pain of her jilted suitor Mr Schjåltz - is an entirely different matter. Schjåltz is an acquaintance whom Stenberg does not hold in high regard. Stenberg becomes implicated in Schjåltz's courtship troubles when they meet accidentally during walks around the town. Schjalttz confides his troubles to Stenberg and asks him to speak on his behalf to Miss Burgerus's parents. At one point in their conversation, Schjåltz bursts into tears, about which Stenberg writes:

I once again took a walk with Inspector Schjåltz during which our conversation was of the same nature as the last time, with the exception that after he had complained for a while, he started to cry bitterly over his misfortune, whereupon I thought: this was all too milksoppy; ${ }^{64}$ if I were to cry over the loss of a girl, that would be all too weak. ${ }^{65}$

With his use of words such as 'milksop' and 'weak', it is difficult not to see Stenberg's description of Schjåltz's behaviour as a denunciation of his masculinity. Historian Jonas Liliequist has described how the gendered norms that affected Swedish courtship practices were 'basically settled by law and tradition, which stipulated that the male was to be active and propose and the female to be passive and respond'. ${ }^{66}$ Consequently, Liliequist notes that a certain degree of male assertiveness was expected in the courtship process. From this perspective, it can be argued that in his emotional despair and requests for help, Schjalltz contradicts the assured behaviour that was expected of a male suitor. While Miss Burgerus's illness is framed as a logical extension of her situation, Schjåltz's grief over losing the girl he loves due to parental objection

64 Stenberg uses the word mesaktigt. The derogatory word mes is translated as 'milksop' in Gustaf Widegren's Swedish-English dictionary from 1788: Gustaf Widegren, Svenskt och engelskt lexicon (Stockholm, 1788).

65 Stenberg, Levernesbeskrivning, 3:210.

66 Jonas Liliequist, 'Masculinity and Virility: Representations of Male Sexuality in EighteenthCentury Sweden,' in The Trouble with Ribs: Women, Men and Gender in Early Modern Europe, ed. Anu Korhonen and Kate Lowe (Helsinki: Helsinki Collegium for Advanced Studies, 2007), 57-81 (70). Anthony Fletcher writes of similar demands on male assertiveness in 'Manhood, the Male Body, Courtship and the Household in Early Modern England,' History 84, no. 275 (1999): 427-28. 
is regarded with disdain. Thus, this example speaks to the gendered connotations of pain and illness brought on by love, as Stenberg frames it as a natural reaction in women, while even the emotional upset at the loss of love is considered unmanly.

However, men do not appear to be entirely excluded from the discourse of lovesickness, as Stenberg himself at one point is assumed to be ill from love. This happens in 1788, when Stenberg is working as a house chaplain in an aristocratic family in Finland. His hostess, a baroness, has encouraged him to reveal his tender feelings for an aristocratic girl in a neighbouring family. Stenberg eventually does so by slipping her a written verse. A short while after this he becomes bedridden with fever, at which point the baroness has had the opportunity to talk to the girl about Stenberg's gesture and relays to him that the girl had expressed a disinclination to marry a clergyman. Stenberg quotes the baroness as saying to him:

Mr Magister should not let this rejection affect his mind so. Maybe the disquietude over this has laid the base for his illness; at the very least it might worsen it. Instead, try to forget this and try to be merry. God has surely designated his future lot in this regard, which might be much more fortunate than this: try to be content, so he can soon become well again, so he can also after a while forget her much more easily. ${ }^{67}$

Stenberg describes himself assuring the baroness that this rejection did not distress him and was not the cause of his illness, having already come to his senses and realised the small chance of any positive response. It might be considered a telling fact that a woman assumes that Stenberg is ill from love, while he actively distances himself from a type of framing that would have indicated a vulnerability to dashed romantic hopes. From Stenberg's perspective, illness caused by love can be experienced by women from all social classes but is distinctly perceived as unmanly. As was the case in Britain, the examples referenced above indicate that illness related to love was associated with women in late eighteenth-century Sweden. Although it could be assumed that illnesses associated with love were a means of intentionally communicating emotions and desires in an indirect manner, Stenberg never reflects on these illnesses as staged or conscious efforts to convey emotions. Instead, all instances of illness are described as actual, somatic afflictions. Consequently, the interrelation between unhappiness in love and actual somatic illness is presupposed and illustrates a strong belief in the connection between emotion and illness.

67 Stenberg, Levernesbeskrivning, 2:243. 


\section{$4 \quad$ Love and Insanity in the Life Description of Pehr Stenberg}

While the examples presented above are of illnesses that could include mental symptoms, but were also seen as physical, there are also instances in Stenberg's description where insanity is regarded as the result of unhappiness in love. 68 Thus, love is framed as the primary cause of insanity.

There was a broad range of factors considered to be causes of insanity during the eighteenth century, among them medical, moral and religious. ${ }^{69}$ Popular conceptions also often overlapped with those of the medical profession. In his study of madness in eighteenth-century Scotland, R. A. Houston exemplifies how popular views of the causes of madness included childbirth, excessive drinking, bereavement, financial troubles, hereditary factors, blows to the head and palsy. ${ }^{70}$ This multiplicity of explanatory factors is mirrored in the table that lists the causes of insanity of the patients admitted to the Bedlam asylum during the early nineteenth century. Here childbirth, grief, drinking, hereditary factors and head injuries all feature. ${ }^{71}$ Similarly, the first psychiatric treatise published in Swedish in 1813 listed a plethora of causes behind madness. ${ }^{72}$

Love formed part of this complex pattern of potential factors behind mental illness and was an established explanation in the institutional care of the mentally ill. In the Bedlam table mentioned above, love was cited as the fifth most common cause of insanity. ${ }^{73}$ Insanity also formed part of the diagnostic picture of lovesickness itself, as mania was believed to result from untreated cases. ${ }^{74}$

Like lovesickness, madness was increasingly viewed as a feminine affliction during the latter part of the eighteenth century. Elaine Showalter has shown how the 'appealing madwoman' came to replace 'the repulsive madman' in the English cultural imagination. ${ }^{75}$ The same process appears to have taken place in Sweden. Karin Johannisson has pointed out how madness was increasingly

68 Hereafter, I use 'madness' and 'insanity' as synonyms.

69 Roy Porter, Mind-forg'd Manacles: A History of Madness in England from the Restoration to the Regency (Cambridge, MA: Harvard University Press, 1987), x.

70 R. A. Houston, Madness and Society in Eighteenth-Century Scotland (Oxford: Clarendon Press, 2000), Chapter 7 .

71 Porter, Mind-forg'd Manacles, 34.

72 Erik Gadelius, Galenskap (Stockholm, 1813).

73 Roy Porter, 'Love, Sex and Madness in Eighteenth-Century England,' Social Research 53, no. 2 (1986): 217-18.

74 See note 33 above.

75 Elaine Showalter, The Female Malady: Women, Madness and English Culture 1830-1980 (London: Virago, 1987), 9. 
linked to women during the late eighteenth century. Women were depicted as strongly affected by their emotions and their madness as more outwardly manifested. ${ }^{76}$ During the same time period, cultural images of women who had gone mad from love became commonplace. Helen Small has shown how stories about deserted women who had fallen into insanity abounded in sentimental prose, poetry, drama and paintings during the last decades of the eighteenth century and the first decade of the nineteenth century. ${ }^{77}$ This association between women, mental instability and disappointment in love can also be found in Swedish medical reports. In 1773, prominent physician Johan Odhelius was ordered by the government to observe the mental state of a young maid who, after first having fallen into a vegetative bedridden state, had started giving ecstatic, illicit sermons from her bed - sermons that were beginning to draw popular attention. Odhelius concluded that the maid was prone to nervous illness, which caused her heated religious fantasies. However, he could not say whether 'some failed love or other passion' was the primary cause of her illness, although he knew this most often to be the case. ${ }^{78}$

This association between women, unhappiness in love and madness is also clearly manifested in the life description of Pehr Stenberg. The propensity to go insane from love is explicitly gendered by Stenberg, who believes that women run a greater risk of this due to their tenderness of feeling..$^{79}$ Consequently, romantic entanglements are always freighted with the risk of female madness.

Despite a very limited number of asylums existing in Sweden during this time ${ }^{80}$ Stenberg does in fact encounter one closely: Själö hospital, located on an island outside Åbo. Here, he visits the priest serving the asylum chapel and is permitted to meet the inhabitants of the asylum. As some of the patients claimed to be kings or queens while some claimed to be in love, Stenberg draws the conclusion that 'pride and love were the two main causes of insanity.' ${ }^{81}$ As unhappiness in love was framed as a prominent factor in madness,

76 Karin Johannisson, Kroppens tunna skal: sex essäer om kropp, historia och kultur (Stockholm: Norstedt, 1997), 137.

77 Helen Small, Love's Madness: Medicine, the Novel, and Female Insanity, 1800-1865 (Oxford: Clarendon Press, 1996), 11. For more on representations of women and madness in eighteenth-century writing see Chapter 6 in Allan Ingram and Michelle Faubert, Cultural Constructions of Madness in Eighteenth-Century Writing: Representing the Insane (Basingstoke: Palgrave Macmillan, 2004).

78 Handlingar, angående den predikande pigan Carin Persdotter från Neriket och Hardemo socken (Stockholm: 1773), 11.

79 Stenberg, Levernesbeskrivning, 4:26o.

8o Roger Qvarsell, Ordning och behandling: psykiatri och sinnessjukvård i Sverige under 18oo-talets första hälft (Umeå: Umeå universitet, 1982), 47-49.

81 Stenberg, Levernesbeskrivning, 2:320. 
courtship - a complicated endeavour in itself - was even more precarious. Stenberg stresses the importance of men acting in a manner that does not cause a woman pain, as romantic disappointment could have lifelong consequences for her soundness of mind. He is critical of rakish behaviour he encounters and is fearful of being viewed as romantically dishonest himself. In these ideas, there are echoes of contemporary discourse in which male and female sexuality were increasingly cast in a different light. Faramerz Dabhoiwala has emphasised how perceptions of the rapacious sexuality of men and relative sexual passivity of women were established during the eighteenth century in Britain. Dabhoiwala partly attributes this to the rising popularity of the novel in which men's deceitful attempts at seduction were a prominent theme. ${ }^{82}$ Jonas Liliequist has argued that a similar discursive shift took place in Sweden, where male sexuality was increasingly viewed in medical, legal and literary discourses as urgent and difficult to control. ${ }^{83}$ It is likely that the changing sexual norms of Swedish society also played a part in Stenberg's perception of romantic dishonesty, as the legislative changes previously mentioned enabled men to escape claims of paternity to a much higher degree. ${ }^{84}$

As a clergyman, Stenberg also mediated in breach-of-promise cases where women had been abandoned by their suitors, likely affecting his perception of suitors with dishonourable intentions. ${ }^{85}$ These issues come to the fore in Stenberg's verbal exchanges with an officer named Cumlander, whom he met while in Finland. Cumlander had made one of the maids in the household in which Stenberg was staying pregnant, but was officially denying her claim that he was the father. Their conversation falls on the recent marriage between the only daughter of a wealthy farrier and a local man. According to Cumlander, he himself was the reason why the union had taken so long to complete. Visiting the household by chance around the time that the banns were to be proclaimed, he had the idea of hoaxing the girl and pretending to want her for himself, flattering her with sweet compliments. The girl had delayed her marriage, until she realised that her new suitor had not been serious in his intentions. Cumlander states that he had wanted to amuse himself with her credulity and see what effect his words would have. Stenberg recounts the reply he gave him upon hearing this:

\footnotetext{
82 Faramerz Dabhoiwala, The Origins of Sex: A History of the First Sexual Revolution (New York: Oxford University Press, 2012), Chapter 3.

83 Jonas Liliequist, 'Between Passion and Lust: Framing Male Desire in Early Modern Sweden,' in Framing Premodern Desires: Sexual Ideas, Attitudes, and Practices in Europe, ed. Satu Lidman et al. (Amsterdam: Amsterdam University Press, 2017), 211-32.

84 Lindstedt Cronberg, Synd och skam, 180-81.

85 For a discussion of this, see Stenberg, Levernesbeskrivning, 4:64.
} 
But was this not very badly done, to lead a girl astray like this and flatter her without being serious in the least? Should he not keep in mind that a girl is soon persuaded to believe what she wants to believe, and when she is so infamously betrayed in her hope, she can easily become unhappy for all her days. For such reasons many girls have gone insane from love, and you will have to bear this on your conscience. ${ }^{86}$

Cumlander's behaviour as interpreted by Stenberg was not only duplicitous, but had the potential to make a woman insane.

For Stenberg himself, this became an issue in 1786 when he worked as a house chaplain for an aristocratic family. He had asked a member of the family, a woman several years his senior, to marry him, only to later form an unfavourable opinion of her character and regret his proposal. Although the woman had declined his offer and showed no real inclination to marry him, Stenberg describes how it pained him to rescind it:

I have always regarded lack of fidelity in matters of love and marriage with disgust; particularly as many thereby not only have gained deep and painful sorrow, but have also quite often lost the use of their senses. And that I would now myself become - or at least in her eyes seem to be - the one to cause her such misery, pained me quite a bit. ${ }^{87}$

The danger brought on by rakish suitors also makes Stenberg protective of his family members. In 1802 , while married for the second time, he is keen to ascertain whether a man courting his sister-in-law has honourable intentions. He describes starting a discussion with him about the way in which some men feign courtship with women, claiming that such a man is

without feeling for her pain and all the bitter tears she - maybe for the rest of her days - will have to shed; and does not remember that for human beings nothing is more delicate than love, especially for women, who by nature are quite tender of feeling and are thus often hurt deeply and bitterly, so that they quite often lose their minds for the rest of their days. At one point this will burn deeply in the conscience of such gentlemen, when they are held accountable for this. ${ }^{8} 8$

86 Stenberg, Levernesbeskrivning, 1:446.

87 Stenberg, Levernesbeskrivning, 2:197.

88 Stenberg, Levernesbeskrivning, 4:26o. 
He goes on to write that he was pleased to find that the suitor completely agreed with his view on this issue and that the couple did actually get married. Stenberg's phrasing of accountability appears to allude to the potential punishment from God, indicating the severity of the infractions perpetrated by dishonest men.

In the examples presented above, the cause of female madness is framed as the unconscionable behaviour of men. Thus, there is a clearly defined agent that is explicitly responsible for the onset of this type of mental illness. According to Stenberg, this agent should be held accountable for ruining another person's life. Although ascribing the responsibility to the actions of men, this reasoning clearly reinforces perceptions of female emotional vulnerability and general fragility, positing abandonment and deceit in love as something which could permanently disrupt a woman's mental equilibrium. Although no explicit distinction is made by Stenberg, romantic betrayal, deceit and abandonment are described as particular causes of female insanity. In contrast, the illnesses caused by love that include physical symptoms are related to unrequited love or parental objection to choice of marriage partner.

\section{5 \\ Conclusions}

In the everyday situations examined above, a strong link between emotional experience and individual health can be discerned. Medical complications were presumed to follow from the emotional turmoil brought on by love. Consequently, love was framed as a factor that caused both physical and psychological illness. Gender played a significant role in this framing process, as symptoms of illness exhibited by women were more likely to be perceived as caused by romantic troubles. Consequently, assumptions of female emotional vulnerability affected how female illness was framed.

There are essentially two types of illnesses related to love that are portrayed in this source material, one that includes physical symptoms and one that is limited to the mind. Examples including physical symptoms are primarily caused by unrequited love and parental objection to choice of marriage partner. These illnesses are portrayed as being essentially transitory, with neither Stenberg nor anyone else alluding to these conditions as being life-long afflictions. For instance, Stenberg never assumed that the suffering of the maid Lisa would be permanent. Although they lived in the same small town, there is no mention of Miss Burgerus becoming physically ill for the rest of her life because she did not marry the man of her choosing. In hindsight, we can suspect that these illnesses provided a means for women to intentionally communicate emotions, 
desires and resistance in situations where a more direct form of communication was hindered by social convention or other outside forces. However, this is not reflected in the source material, in which these illnesses are framed as somatic. Consequently, a strong interrelation between emotional turmoil and actual somatic illness was presumed.

Madness framed as arising from unhappiness in love was portrayed as a more permanent state, primarily caused by romantic abandonment and deceit. Consequently, the risks of these kinds of romantic disappointments were perceived as grave by Stenberg, as they potentially altered the course of a woman's life forever. A specific agent caused this illness - a man without honourable intentions. Thus, a rakish man not only lacked honour but also jeopardised a woman's future health and well-being. This framing particularly reinforces perceptions of female emotional fragility, as romantic mistreatment was depicted as something from which a woman might never recover. Although these examples relate to a Swedish context, they speak to the strong link between emotion and ill health that characterised early modern European perceptions of illness as well as the increasing tendencies to define illness related to love as a specifically female affliction which marked the eighteenth century. 